\title{
Genesis of Moral Freedom in Kant
}

\author{
Jacinto Rivera de Rosales († 2021) \\ (La Universidad Nacional de Educación a Distancia, Madrid; jrivera@fsof.uned.es) \\ ORCID: 0000-0001-6808-0463
}

\begin{abstract}
In Kant's writings, we can discover four key moments in the realization of moral freedom: i) The original possibility of being free, ii) The act described by Kant as radical evil, iii) The opposite act, that is, an inner conversion to good, and, finally, iv) The long process of the self-development of virtue extending to immortality. There are further issues such as the double concept of moral evil, and practical temporality. Moral freedom is originally located (and presupposed in Kant's transcendental deduction) in the individual, her decisions, and the maxims or principles that guide her actions, even though a community (as both a "kingdom of ends" and social reality) provides the scope wherein all this takes place and its socially and historically-situated shapes. This paper tries to systematize these crucial stages of Kant's moral philosophy with the focus on the concept of virtue.
\end{abstract}

Keywords: Kant; moral freedom; moral evil; practical temporality; virtue; immortality.

In Kant's writings, we can discover four moments in the genesis of the development of moral freedom. These are as follows:

i) The moment of the original possibility of being free,

ii) The act that Kant describes as radical evil,

iii) The inner revolution, or conversion toward good, respectively, and

iv) The long process of virtue.

I am not dealing here with the development of freedom in the human community, as Kant discusses it in his Conjectural Beginning of Human History (AA VIII, 107-123) ${ }^{1}$ which goes from the protection of nature to the state of freedom, or with the evolution of legal freedom, as in Idea for a Universal History with a Cosmopolitan Purpose (AA VIII, 15-31)2, which addresses a perfect political constitution both within the state and in the mutual

1 I. Kant, Muthmaßlicher Anfang der Menschengeschichte (1786). Citations to Kant will be provided on the basis of the Akademie-Ausgabe by volume and page (for instance: AA I, 1-2; 3-4). English quotations will be edited according to the Cambridge edition of the Works of Immanuel Kant, except for the Critique of Pure Reason where citations will use the standard A/B edition pagination (for instance: Kant, CPR, A 709/B 737).

2 I. Kant, Idee zu einer allgemeinen Geschichte in weltbürgerlicher Absicht (1784). 
relations between states. The topic of this article is rather the genesis of moral freedom, which Kant locates specifically in the individual, his internal decisions, and the maxims or principles that direct his actions, even if the community or kingdom of ends is the realm or context wherein all of this occurs.

\section{On the Original Innocence}

The first moment in the genesis of moral freedom is a structural element that we could call the original possibility or original innocence. Freedom appears, in Kant, as the capacity to initiate a real series of phenomena in the world, without itself being determined by an external cause, that is, without itself falling under the law of causality that governs phenomena and links them to each other, ${ }^{3}$ but rather is an original action [ursprünglich] that initiates its action itself. As we know, he argues for this first by placing ontological limits on natural causality and determinism in the Critique of Pure Reason, thus leaving possible room for freedom, and second by showing that freedom is the ratio essendi of moral consciousness, because only in a free being can something like a duty appear. Only in a free being can a moral demand arise and be grasped, so the mere fact that one has a moral conscience reveals itself as a condition for the possibility, existence, and reality of a freedom, and of one that takes itself as its own task.

How, then, does this free action arise? If we come closer to seeing what occurs within this act of moral freedom, we see, first, that it develops in the realm of reflective consciousness, which is the location of judgment and reason, including practical reason. It is not given in a pre-reflective, involuntary, or sleeping consciousness, or in an instinctive consciousness, but in one that has arrived at a concept, reflective knowing of a law, or maxim, which involves ideal actions that indicate possibilities, and in this case, possibilities of action. Second, we see that, since it is freedom, or an action that begins with itself, we find in it the ability to decide on one of these possibilities and thus, to determine its own will.

Consequently, we encounter here two elements: concept and volition. On the one hand, there are concept and possibilities, from which proceeds autonomy that consists in acting according to the concept that freedom has of itself. On the other hand, there is a free volition that decides

3 That is why Kant tells us in the Introduction to the Critique of Judgement that freedom is not properly the cause [Ursache], but rather the foundation [Grund], of the causality of natural things in that real series of phenomena to which it gives rise (AA V, 195). However, Kant does not pause to explain wherein the difference between these two concepts consists. We could think that the cause of a phenomenon must be objectively another phenomenon, but freedom is not a phenomenon, and consequently interacts in a different manner. In the "Critique of Teleological Judgement," we are shown that it becomes an object, it appears as an organic body. We could then conclude that our moral freedom acts in the world through its synthetic identification with our body [Leib], and thus, we can understand what Kant is indicating when he says that when moral freedom comes to realize its ends in nature, "the same causality of freedom (of pure and practical reason) is the causality of a natural thing that is subject to it (of the subject, as man, consequently considered as phenomenon)"; in German: "selbst die Kausalität der Freiheit (der reinen und praktischen Vernunft) ist die Kausalität einer jener untergeordneten Natursache", "des Subjekts, als Mensch, folglich als Erscheinung betrachtet" (AA V, 196, note), that is, the causality of the human being as a body-mind whole (e.g., Rivera de Rosales 2002). 
for itself to act according to one of the possibilities before it. Will, Kant tells us, is a "faculty of determining its causality according to a representation of rules"4.

Let us consider now the first element of the concept and the possibilities it offers, which, according to Kant, has the form of a moral law and maxims. These shape the first moment of moral freedom, making it possible by means of the capacity for reflection and the ideal distance in consciousness that the concept provides regarding the immediate reality of the world. This ideal distance extends to the rational demand of the unconditioned that surpasses everything given empirically and allows us a comprehension of freedom's mode of being, which is distinct from the world's mode of being. Moral consciousness is thus a reflective knowledge, which is certainly not a direct objective acquaintance with the world, but rather a consciousness that freedom has of itself and its mode of being or, as is said in the $\mathrm{KpV}$, moral consciousness is the ratio cognoscendi of freedom. It is so for the philosopher, but because it is so for itself, and because thanks to it the subject is and knows himself to be responsible for his acts, that is to say, free: "This fact [of reason, namely, the moral law] is united inseparably with consciousness of the free will and is the same

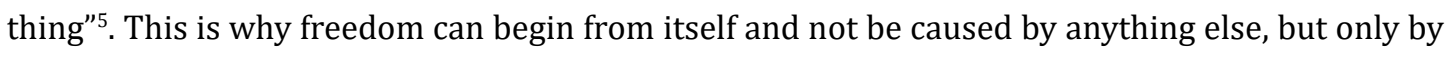
itself and its own decision. The concept sets us free.

We can add to what Kant said that the concept presupposes language, because it is in language that it gives an objectivity to itself and finds its expression. There can be no consciousness without a world, or a concept without language, because consciousness, selfconsciousness, and freedom are not transcendent substances, but rather transcendental actions. However, language can only arise in a community, wherein alone communication is needed. Consequently, this act of reflective consciousness and freedom, although it is an individual act, like all acts, is only possible in a community. In fact, it is an act that binds us to the community, as we will see.

However, the concept is not enough. The concept alone, Kant tells us, is empty of content. A reality, of which it is a concept and an understanding, is also required, and indeed, a reality of which the moral concept is consciousness. The moral concept is the consciousness of freedom as a reality in itself, which is the only reality we can affirm based on any ground, and it involves real and ideal spontaneity rather than mere ideal reflection or mere concept. We have no intuition (in the sense Kant uses the term) of this reality of freedom, but he speaks of a moral feeling, that is, the feeling of dignity we have before the moral law, and calls it "respect" [Achtung]. Moreover, if we consider the moral law as the consciousness that freedom has of itself, because it is not a heteronomous law that comes from outside, then we can say that it is the feeling wherein freedom manifests its force and reality beyond the concept. Through this feeling, we recognize freedom in

4 In German: “(...) ein Vermögen (...) ihre Causalität durch die Vorstellung von Regeln zu bestimmen" (AA V, 32). The will is "the capacity to act according to the representation of laws, that is, according to principles" [das Vermögen, nach der Vorstellung der Gesetze, d.i. nach Prinzipien, zu handeln] (AA IV, 412).

5 “(...) daß dieses Factum mit dem Bewußtsein der Freiheit des Willens unzertrennlich verbunden, ja mit ihm einerlei sei" (AA V, 42). 
the individuality of each person and his act, because action and feeling are related to individuality and particularity, while the concept is related to universality.

We have thus, these two elements: concept and reality in itself, which come to be felt in the moral feeling of respect, and this reality is the source of moral consciousness and the capacity to decide for oneself through its concept or autonomy. This feeling of self has its origin in the reality and the act of freedom in front of its concept, that is, it is given in the concrete, individual action of freedom, which can choose good or evil, in contrast to the universality and obligation of the moral law. Consequently, in this first moment of moral freedom, we encounter an original being and knowledge of ourselves that is not produced by the world. Nonetheless, without a world, they would not have arisen, because possessing consciousness of oneself implies distinguishing oneself from the other, and there would be no consciousness of freedom or "I think" without consciousness of the world or without the action of knowing and transforming it ${ }^{6}$.

Nonetheless, we have here just the condition for the possibility of a complete act of will that is only given when it produces an act, which will occur in the second moment of our genesis. This first element of moral liberty makes all free decision possible, and is the ground on which it stands and with which it forms an indissoluble whole. They arise together, but it was necessary to analyze them separately in order to become aware of the complex whole that contains freedom's own proper mode of being. This very first element does not exist without the second element, or the act of decision, since it cannot be thought that freedom was first a substance, mere power, or potency that only acted sometimes, or after the decision, but rather that it is always an action, as the first element also arises only with action. The important thing to see here is that this first moment makes every decision free and imputable to the individual subject ${ }^{7}$. Consequently, this first moment will always be present in the rational individual, unless his freedom is to be destroyed, and it will be present from the age of reason and throughout his entire rational life provided he does not lose it due to some grave illness, madness, or dementia. By saying "always" we expose here a temporal determination that must be elucidated.

Kant tends to assimilate the first element, which makes all free decision possible, mythically with the earthly paradise, and given that its first free determination led to moral evil, speaks of it as the state of innocence prior to the fall. Adam would be the prototype of what we do normally (AA VI, 41-44). This is how he expresses it clearly in a passage in Religion within the Limits of Reason Alone:
All bad action [we could say: all free action], if one seeks its rational origin, would have to be as if man incurred it starting directly from the state of innocence. For, whatever his previous behavior might have been and whatever natural causes might have influenced him, his actions, whether encountered within or outside of him, are still free and not determined by any of these causes. It can be judged,

\footnotetext{
6 Freedom distinguishes us from nature and, at the same time, binds us to it as the place wherein freedom has to be realized, according to Kant's explanation in the Introduction to KU. This obligation and responsibility also distinguish us from other rational beings and, above all, bind us to them, but with different laws.

7 We find the spontaneity of life, and even of subjectivity, in newborn children and animals (or in sleeping or alienated human beings, etc.), too, but they lack the concept, or the reflective consciousness, and therefor do not rise to the capacity for moral freedom.
} 
and must always be thought as an original use of his power of choice. (...) And no matter how bad someone might have been until the moment immediately prior to a free action (even including habit as a second nature), it was not only his duty to be better, but even now it is his duty to improve himself. Later, he must be able to do it, and if he does not, he is so susceptible in the moment of the action that has been imputed to him, and he is so subject to this imputation that it is as if he, endowed with the natural disposition toward good (which is inseparable from freedom), had passed from the state of innocence to evil (AA VI, 41) ${ }^{8}$.

\section{Radical Evil}

Kant examines the second moment, which he called radical evil [das radikale Böse], in the first part of Religion. We now turn to this first act of free volition, which implies and includes in itself the moment we examined before, since that moment made it possible as a free act. As we know, and according to our author, moral evil consists in the power of choice giving preference to inclinations rather than to the moral law in its maxims, which is to say that the subject opts to attend to his finitude rather than his free being and does not respect freedom in himself or others as something original but subordinates himself to the dominion of the world or to his passions against others, such as anger, envy, and revenge. Evil involves, consequently, an inversion [Umkehrung] of the correct hierarchy of the principles ${ }^{9}$ that moves toward non-recognition and destruction of freedom. In evil also, there is knowing (concept) and act, or reflective consciousness and volition: "Man recognizes the moral law and, nonetheless, has allowed in his maxim the (occasional) deviation regarding it" (AA VI, 32) ${ }^{10}$.

In the greater part of Kant's work, we find a conception of evil wherein evil arises as a result of a kind of mechanics of forces, such that moral evil is due to the weakness of freedom and reason against in the greater force of desires on account of the subject's preference for happiness, or evil occurs because of the "impotence of reason over inclination,"11 or for the debility of freedom against our dependencies on the world. Accordingly, moral evil would not be strictly an act of freedom but, rather, its absence: a release or passivity, or a defeat by opposing superior forces. We can find this conception even in a work as late as the Introduction to the Metaphysics of Morals of 1797:

8 "Love yourself morally, that is, according to the constitution of your spirit before it was corrupted. The evil that came later in you, before you showed reason, must not provoke aversion against yourself. Honor yourself with respect. Do not make yourself into a thing" (AA VI, 41). In original: "Liebe dich selbst moralisch d.i. nach der Grundanlage deines Gemüths ehe du verdorben warest. Das nachher in dir gekommene Böse selbst, ehe du Vernunft bewiesest, muß dir nicht Abscheu erregen gegen dich selbst. Ehre dich selbst Achtung. Mache Dich nicht zur Sache" (AA XXIII, 404).

9 Good and radical evil depend on which of the two motives the power of choice takes as the supreme condition, or which of the two motives, finitude or originarity, the person makes the condition of the other (see AA VI, 36).

10 "Er ist sich des moralischen Gesetzes bewußt und hat doch die (gelegentlich) Abweichung von demselben in seine Maxime aufgenommen" (AA VI, 32).

11 "Ohnmacht der Vernunft über die Neigungen" (AA XIX, 133). "Le mal radical (...) est la simple impuissance à rejoindre la loi. En ceci réside sa racine transcendantale" (Philonenko 1981/3, vol. II, 158). 
But freedom of the power of choice cannot be defined by means of the capacity to choose between acting for or against the moral law (...) so that freedom can never allow that the rational subject can make a decision that contradicts its legislative reason (...). Only freedom that conforms to the internal legislation of reason is strictly a capacity; and the possibility of departing from it, an incapacity [ein Unvermögen] (AA VI, 226-227) ${ }^{12}$.

To be sure, freedom is realized adequately only in goodness.

However, in the first part of Religion, we find a different version of Kant's idea of moral evil, which I consider more complete. For evil to be moral and imputable to the subject, it must follow from his free act (see AA VI, 34-35; AA XVII, 430; see also Rivera der Rosales 2007, 9-40) and not from its absence. It must consist in an "intelligible act" [intelligible That] (AA VI, 39, note) and not merely a sensible one, since "nothing is morally wrong" (or so to say, capable of being imputed) unless it is our own act"13.

It must be an act of freedom (since, otherwise, the use or misuse of man's power of choice in relation to the moral law could not be imputed to him, and neither his goodness nor badness could be called moral). Consequently, in no object that determines the power of choice by inclination, and in no natural impulse, can the foundation of evil be discovered, but rather only in a law that the power of choice gives to itself for the use of its freedom, that is to say, only in a maxim (AA VI, 21) ${ }^{14}$.

According to this, moral evil does not consist rest in a conflict between inclinations and freedom, or between finitude and originarity [Ursprünglichkeit]. In other words, it does not arise from the difference between the higher and lower faculties of desire, as

12 “(...) daß die Freiheit nimmermehr darin gesetzt werden kann, daß das vernünftige Subject auch eine wider seine (gesetzgebende) Vernunft streitende Wahl treffen kann (...) Die Freiheit in Beziehung auf die innere Gesetzgebung der Vernunft ist eigentlich allein en Vermögen; die Möglichkeit von dieser abzuweichen ein Unvermögen“ (AA VI, 226-227; see also AA XXIII, 248249; 383; AA XXI, 470-471; AA XVII, 314; 317; 318). The latter ends by saying that wanting evil "is not properly a capacity, but rather the possibility of being passive [eine Möglichkeit zu leiden]. Although evil actions are under [unter] freedom, they do not happen through [durch] freedom" (Dieses /das erkannte Böse/ ist auch nicht eigentlich ein Vermögen, sondern eine Möglichkeit zu leiden. Böse Handlungen stehen zwar unter der Freyheit, aber geschehen nicht durch sie) (AA XVII, 318).

13 "Nun ist aber nichts sittlich-(d.i. zurechnungsfähig-)böse, als was unsere eigene That ist" (AA VI, 31).

14 "Dieser subjective Grund muß aber immer wiederum selbst ein Actus der Freiheit sein (denn sonst könnte der Gebrauch oder Mißgebrauch der Willkür des Menschen in Ansehung des sittlichen Gesetzes ihm nicht zugerechnet werden und das Gute oder Böse in ihm nicht moralisch heißen). Mithin kann in keinem die Willkür durch Neigung bestimmenden Objecte, in keinem Naturtriebe, sondern nur in einer Regel, die die Willkür sich selbst für den Gebrauch ihrer Freiheit macht, d.i. in einer Maxime" (AA VI, 21 cf.). Moral evil is not a mere weakness before sensibility, but rather a free decision, and "it is not to be sought in the inclinations, but rather in the perverted maxim and thus, in freedom itself" [welches (das Böse) nicht in den Neigungen, sondern in der verkehrten Maxime und also in der Freiheit selbst zu suchen ist] (AA VI, 58, note; also 59, note). "What man, in a moral sense, is or should, good or bad, he must do or have done himself. Both things must be an effect of his of his free power of choice, or otherwise it could not be imputed to him, and consequently, it could be neither morally good nor bad", in German: "Was der Mensch im moralischen Sinne ist oder werden soll, gut oder böse, dazu muß er sich selbst machen oder gemacht haben. Beides muß eine Wirkung seiner freien Willkür sein; denn sonst könnte es ihm nicht zugerechnet werden, folglich er weder moralisch gut noch böse sein" (AA VI, 44). 
the first concept of moral evil suggested, but it is situated in a second fold that is located within freedom itself, specifically, between the freedom-concept and the freedomdecision, or between the rational will with its universal moral law, or concept, and the absolute spontaneity of the particular power of choice with its maxim and act of volition, ${ }^{15}$ which are thus imputable to it (AA VI, 25, note). Only freedom can affirm or negate itself directly ${ }^{16}$ :

For natural impulses in themselves are innocent and between them and the moral law there is properly no conflict; it is an act of freedom to make the pursuit of the law a maxim for oneself independent of those impulses, or even against them (...). The good principle has no struggle properly against sensibility (of the flesh), since it is innocent, but the propensity to base one's maxim, which is free, on the impulses of the flesh, is the evil principle in us (AA XX, 346-347).

The decision of the power of choice to adapt (or not) its maxims of action to the moral law would be the fundamental decision or "supreme maxim" [die oberste Maxime] (AA VI, 31; also 39, note) that gives rise to the good will (e.g., Rivera de Rosales 2007) or radical evil. "This moral evil is radical, because it corrupts the foundation of all maxims"17. The first fold between the lower faculty of desire and the higher, or the conflict that sometimes exists between inclinations and freedom, still plays an important role here. It contributes, first, to make consciousness of freedom possible, insofar as we become conscious of one force only in its resistance to an opposing force:

All strength [Stärke] is recognized solely by virtue of the obstacles it is able to overcome; but in the case of virtue, the obstacles are natural inclinations that can [but not necessarily] enter into conflict with the moral proposition (AA VI, $394)^{18}$.

Second, as a sometimes-contrary force, it incites evil. Nonetheless, at its root, moral evil must be thought as an act of freedom, which because it is divided into universal will [Wille] and particular power of choice makes it possible and necessary that freedom accept and affirm itself

15 "The freedom of the power of choice is constituted with the peculiarity that it cannot be determined as an action due to any motivating force, but rather only and to the extent that the person accepts it as his maxim (and insofar as he makes it a universal rule according to which he wants to behave); Only in this way can a motivating force, whatever it might be, coexist with the absolute spontaneity of the power or choice (of freedom)"; in German: "die Freiheit der Willkür ist von der ganz eigenthümlichen Beschaffenheit, daß sie durch keine Triebfeder zu einer Handlung bestimmt werden kann, als nur sofern der Mensch sie in seine Maxime aufgenommen hat [es sich zur allgemeinen Regel gemacht hat, nach der er sich verhalten Will]; so allein kann eine Triebfeder, welche sie auch sei, mir der absoluten Spontaneität der Willkür [der Freiheit] zusammen bestehen" (AA VI, 23-24; see also AA VI, 213).

16 In German: "Denn die Naturtriebe sind an sich unschuldig und zwischen ihnen und dem moralischen Gesetze giebt es eigentlich keinen Streit: seine Befolgung aber unabhängig von diesen ja selbst wieder sie sich zur Maxime zu machen ist ein Act der Freiheit (...) Die Sinnlichkeit (des Fleisches) ist eigentlich nicht das was vom guten Princip zu bekämpfen ist denn die ist unschuldig sondern der Hang seine Maxime nach dieser ihren Antrieben zu nehmen welche frey ist, ist das böse Princip in uns" (cf.).

17 "Dieses Böse ist radical, weil es den Grund aller Maximen verdirbt" (AA VI, 37).

18 "Alle Stärke wird nur durch Hindernisse erkannt, die sie überwältigen kann; bei der Tugend aber sind diese die Naturneigungen, welche mit dem sittlichen Vorsatz in Streit kommen können," which would imply self-restraint according to the rational principle of freedom (cf.). 
freely. Clearly, this possibility allows that freedom can also deny and demean itself, which is moral evil. Freedom is thus the capacity for doing good or evil, which are possibilities contained in its concept ${ }^{19}$. This does not imply that freedom involves an indifference before good and evil, because as I said, freedom is fully realized as such only in good, and for this reason, moral obligation is directed toward the good. Consequently, freedom is the capacity of acting according to its own law, autonomously, and in conformity with its original mode of being, but this capacity implies the possibility of not following its law, and of negating itself and committing injustice, insofar as only this possibility allows the free realization of freedom ${ }^{20}$.

Let us continue analyzing this second moment and consider why Kant affirms that this first act of moral freedom is morally evil. According to him, "the history of nature began with the good, since it is the work of God; the history of freedom, with moral evil, since it is the work of man"21. Very well, but the moral evil of the first act of freedom cannot be explained by the idea of original sin, as Christianity thinks, "since the actions of the power of choice cannot contain something inherited in themselves," 22 insofar as they are free, individual, and imputable to the individual subject and we can only be held accountable for our own acts (AA VII, 31; 40). This radical evil can also not be deduced from freedom's mode of being, because only the possibility of evil emerges from it, and not the necessity of evil, and not, therefor, the necessity that the first act of freedom be directed toward evil. Consequently, Kant's claim that the first act is evil can be based solely on experience (AA VI, 32-34), that is, on the moral experience of the existence of evil and injustice in the world and history from their inception, and it is to this experience that he refers us ${ }^{23}$.

To understand the fact that the freedom of reflective consciousness opts first for evil, we could argue that the first act tends to be imperfect, or that, as dependent beings, happiness is "the first thing that we desire unconditionally" (AA VI, 46, note) and "the final subjective end" (AA VI, 6 , note; compare $A A \mathrm{~V}, 484$ ). We could also argue that moral goodness requires reflection, rational development, and moral education, or that, normally, we need to experience the pain generated by evil to turn our principle of action around. Nonetheless, ultimately, we must comprehend evil as an act of freedom that starts from itself.

One final issue that we need to address about this act of freedom is if it occurs inside or

19 For Schelling, who is also inspired to think this in Kant, conceives the formal concept of freedom as the ability to determine oneself according to practical reason, "since what is free acts only according to the laws of its own essence" [denn frei ist, was nur den Gesetzen seines eignen Wesens gemäß handelt] (Schelling, SW VII, 384). "But the real and living concept is that freedom is a capacity of moral good and evil" [Der reale und lebendige Begriff aber ist, daß sie ein Vermögen des Guten und des Bösen sey] (Schelling, SW VII, 352).

20 Let us say that the difference between the universality of the law and the particularity of the power of choice shows us again that this act of freedom is only possible within the framework of a plurality people, wherein the difference between the individual and the community is objectified.

21 "Die Geschichte der Natur fängt also vom Guten an, denn sie ist das Werk Gottes; die Geschichte der Freiheit vom Bösen, denn sie ist das Werk Gottes" (AA VIII, 115).

22 “(...) denn willkürliche Handlungen können nichts Anerbendes bei sich führen“ (AA VIII, 123).

23 Here perhaps we could make use of Heidegger's expression "proximally and for the most part" [zunächst und zumeist] from Being and Time to conclude: In the greatest number of cases and firstly, it happens that the first act of freedom goes toward evil. 
outside of time. We have seen that Kant locates it within freedom and so, considers it an intelligible act, rather than a phenomenal one, which establishes the human being's intelligible character (AA $\mathrm{VI}, 37$ ). If we recognize that time is the a priori sensible form of objects, then we would have to place this act outside of all time. Kant tells us that "it is an intelligible act, cognizable only by reason without any condition of time [ohne alle Zeitbedingung]" ${ }^{24}$ and assures us that "as an intelligible act, it is prior to all experience [vor aller Erfahrung]"25.

Schelling has provided this idea the furthest, referring expressly to Kant (Schelling, SW VII, 384) in his Philosophical Investigations on the Essence of Human Freedom (1809). He also locates freedom "outside of all causal connection as well as beyond all time"26. Accordingly, the free individual decision to do good or evil "falls outside of all time and, consequently, coincides with the first creation (although as an event different from it),"27 that is, at the beginning [Anfang] of creation, whereby time commences, in eternity [Ewigkeit], and this decision determines the entire temporal life of the individual. It is an action that precedes [vorangeht] and constitutes the individual's consciousness and "even determines the mode and constitution of his corporality" 28 . Schelling appears to approach here the Platonic myth of Er (Plato, Politicus 614 b-621 d) to which Leibniz's conception of the divine creation of the world should be added.

It must be said that certain renowned Schellingians believe and defend this point of view, but I find it contains serious difficulties, which can help us to reflect on this issue in Kant. The first and greatest of these difficulties is that an individual cannot possibly determine his moral character (which requires reflective consciousness, concept, and language, that is, a community, as we have seen) prior to all consciousness and his own existence, and even determine his own corporeality, from nothing. Although it might be a beautiful image, it is of a mythological character. Second, if we accept Schelling's idea, the real and conscious man, or the man in time, would cease to be free, insofar as his free act had been converted into necessity, because all his sensible acts and all his life would be necessary consequences of this intelligible act, which could not be changed in the temporal course of his life. Judas could not have acted differently through upbringing or teaching. ${ }^{29}$ Third, although Schelling endeavors to declare that this act does not precede the life of the individual in time, because it is situated in eternity, he cannot avoid temporal expressions, such as "precede," "first creation," or "prior to consciousness," required for comprehending what is said. Fourth and last, in relation to Schelling's philosophy of nature, it must be remembered that he presents nature as prior to Spirit or the world of freedom (as Hegel will do), but this original act of freedom would have occurred without counting on the presence of the individual body or

24 "Jene ist intelligibele That, bloß durch Vernunft ohne alle Zeitbedingung erkennbar" (AA VI, $31)$.

25 "... die als intelligibele That vor aller Erfahrung vorhergeht" (AA VI, 39, note).

26 "... außer allem Kausalzusammenhang, wie außer oder über aller Zeit" (AA VII, 383).

27 “... sie fällt außer aller Zeit und daher mit der ersten Schöpfung (wenngleich als eine von ihr verschiedene Tat) zusammen" (AA VII, 385).

28 "... indem durch jene Tat sogar die Art und Beschaffenheit seiner Korporisation bestimmt ist" (AA VII, 387). 
of nature.

Returning to Kant, I think that the problem regarding the first act of freedom and time resides in his not having reflected sufficiently on different modes of temporality (including those that he uses himself). It appears that the only possible temporality possible would be that of objects, or objective time in CPR, which is ordered by the categories of relation: substance-accident, cause and effect, and reciprocal relations. Freedom, however, is not subject to precisely these relations, because it has a mode of being different from objects. Consequently, Kant concludes that it is outside of all time insofar as causality would not only determine the phenomenal ordering of time but also time as such, which would go against the distinction between intuitions and concepts, or rules of synthesis, and cause it to collapse (AA VII, 386-387). Nonetheless, I would say that there are other temporalities not governed, or not exlusively governed, by these categories, such as the temporality of history, the internal purpose of living beings, or the aesthetic. For instance, Kant claims: "we linger [weilen] in the contemplation of the beautiful, because this contemplation strengthens and reproduces it" $^{\prime 30}$. Likewise, we might consider the temporality of musical or theatrical works. To be sure, all of these events and activities still develop against the background of objective temporality and are datable within $\mathrm{it}^{31}$.

Thus, here in the case of radical evil, we would find a temporality that we could call practical or moral, because every decision and act divides time into a before and after even though they are not determined by phenomenal causality. Let us examine a brief passage that exposes the Kantian ambiguity on this matter. In Religion, Kant tells us that the moral intention [Gesinnung] of accepting (or not) the moral law as the first motive of action in its maxim, is an act of the human being "only insofar as it does not occur in time (that he was one or the other from youth on)"32. First, Kant emphasizes that this act is not produced in time and yet, he places it in the individual's youth. Second, he affirms that this decision will persist forever, but we know that according to him, there is the possibility of an inner conversion toward the good, which can only happen in a moment of time during the individual's life.

In KpV, Kant appears to reduce the age of moral accountability and tells us that a child of 10 years is capable of distinguishing between moral good and evil (AA V, 155) $)^{33}$. We would have been surprised if he had said a child of 10 days could make this distinction, because moral consciousness belongs to the realm of reflective consciousness and requires a developed conceptual and linguistic capacity that a newborn lacks. When a child reaches the age of reason remains imprecise and variable insofar as it depends on his intelligence, reflection, and maturity as well as the education that he receives and the society wherein he lives. In any case, he does not arrive at this state

30 "Wir weilen bei der Betrachtung des Schönen, weil diese Betrachtung sich selbst stärkt und reproduziert" (AA V, 222).

31 Everything real occurs in time and space, but the way of being of the object is not the only one that develops or exists there.

32 “... sondern daß sie nur nicht in der Zeit erworben sei (daß er eines oder das andere von Jugend auf sei immerdar)“ (AA VI, 25).

33 “... selbst Kinder," without specifying their age (AA VI, 48). 
before his birth, but rather in the first years of his life and only after a certain process of learning and personal development. Consequently, when Kant maintains that the first act of freedom "as an intelligible act, precedes all experience," (AA VI, 39, note) it would be difficult to understand that he means any kind of experience, because all knowledge, and so all consciousness, begins with experience, as the CPR affirms. A better interpretation would be that this act is independent of all sensible, concrete experience, as when he assures us that the forms of objective knowing are independent of experience but cannot exist without it. Likewise, when Kant claims that it occurs "ohne alle Zeitbedingung," we must understand that he means it is not determined by the condition of phenomenal causality.

\section{The Inner Conversion toward the Good}

The third moment in the development of moral freedom starts from the two prior moments and consists in an inner conversion toward the good within freedom. This radical revolution involves an inversion in the subject's principles of action whereby the maxim of his power of choice ceases to accept inclination as an ultimate guide, which was the characteristic of moral evil, and takes the moral law as a guiding principle, which compels respect and real, practical recognition of everyone's freedom.

It is not enough that our empirical behavior complies externally with this moral principle, because the evil will or bad Gesinnung can lead us to perform external actions that accord with the law on some occasions for the sake of prudence, "and then, in this case, the empirical character is good, but the intelligible character is still evil,"34 and will produce reprehensible actions on other occasions. The good deed here would be contingent and in favor of world domination. Desire has become civilized, some habits have changed, but not yet in the heart, and so, we have an occasional and merely phenomenal virtue (AA VI, 14; 47). Still, this is not enough for Kant.

To move toward the third moment in the development of moral freedom, there must be another intelligible act within freedom, namely, that the power of choice adopts the moral law as a guiding principle of its maxims and volitions. It must generate, thus, an inversion [Umkehrung] in the guiding principles of action, such that now the moral law and the freedom of every human being are posited as the unconditioned in the supreme maxim of the power of choice, and no longer finitude and particular inclinations. This inversion does not involve nullifying our desire for happiness and our dependency on the world, which would be unnatural and demented, but rather seeking our satisfaction within the framework of the moral law and respect for freedom:

The condition under which the desire for happiness can be consonant with legislative reason, the entire moral prescription consists in this, and the mode of moral thinking consists in the intention to not desire except under this condition (AA VI, 46, note; see also 58; AA VIII, 283; AA V, 25; AA VI, 387) ${ }^{35}$.

34 "... da dann der empirische Charakter gut, der intelligibele aber immer noch böse ist" (AA VI, $37)$.

35 "Daß diese nun objectiv die Bedingung sei, unter welcher der Wunsch der ersteren allein mit 
The inversion of principles does not occur gradually, as only the phenomenal realm would contain degrees (AA VI, 39, note), so Kant regards it as an "explosion" [Explosion], resembling a "new birth" [eine Art von Wiedergeburt] and "a new creation" [eine neue Schöpfung], or a "new epoch" [eine neue Epoche] and an "inner revolution," (AA VI, 47-48, 74; AA VII, 294) that entail a "revolution in the manner of thinking" [Revolution für die Denkungsart] or a "revolution in the mind" [in der Gesinnung] (AA VI, 47), and that initiate a new intelligible character in the subject or individual: a good will. According to the religious symbolism that Kant uses to describe this conversion (AA VI, 47, as in John III, 5), the old man, with his former identity and his fear of finitude, deficiency, and death, must perish in this act and a new man, who takes up his freedom and finitude, must be born. In reality, thanks to this act, the human being establishes a character in himself (AA VI, 48) and "has a character that he creates himself" (AA VII, 321), "(...) because evil (since it involves conflict with itself and does not permit any stable principle within itself) distinctly lacks true character" ${ }^{\prime 36}$. However, in contrast, this inner conversion toward the moral good "founds a character (that is consistent with a practical manner of thinking according to invariable maxims)" ${ }^{37}$.

This inner change is possible thanks to the first moment of freedom, or original innocence, which is always present; that is, it is possible thanks to the concept, reflective consciousness, or moral reason, which appeals to the individual so that he takes it as the ultimate guide of his action, and also thanks to the free and original character of the power of choice, which is capable of starting over by itself at any moment: "Stand up and walk!' (...). This imperative occurs in man by virtue of his own reason, insofar as it harbors in itself the supersensible principle of moral life" $(\text { AA VII, } 47)^{38}$.

This original innocence, or "germ of goodness [Keim des Guten] has remained [note the practical temporality] in all its purity" (AA VI, 45) and now is reinstated, since the subject returns to himself, and to the first fontal moment of his freedom, and thereby, to his original capacity for possibilities and for his own decision ${ }^{39}$. If this root of rational will were corrupted, we would have a diabolical will and it would be impossible to change it, but then we would also have ceased to be free.

Finally, in relation to temporality, we can say that this act of inner revolution, which requires reflection and conscious decision, can only occur during the rational life of an individual, without

der gesetzgebenden Vernunft zusammenstimmen kann, darin besteht alle sittliche Vorschrift und in der Gesinnung, auch nur so bedingt zu wünschen, die sittliche Denkungsart" (AA VI, 46).

36 "... weil das Böse (da es Widerstreit mit sich selbst bei sich führt und kein bleibendes Princip in sich selbst verstatet) eigentlich ohne Charakter ist" (AA VII, 329; see also 292-295).

37 “... welcher einen Charakter (praktische consequente Denkungsart nach unveränderlichen Maximen) gründet" (AA V, 152).

38 In German: 'Stehe auf und wandle!' (...) Der Zuruf geschieht an den Menschen durch seine eigene Vernunft, sofern sie das übersinnliche Princip des moralischen Lebens in sich selbst hat". Kant is here an enlightened rationalist and not a Lutheran fideist.

39 If theoretical, pragmatic, and technical reason was used as a mere instrument in the search for means of satisfaction before, practical reason is posited as a guide now, and consciousness of freedom is posited in the beginning and the ends. 
specifying any particular age during his rational development at which it would occur, since the first moment of moral freedom, which makes it possible, is always present. However, there is also the other possibility, wherein moral freedom also consists, that an individual might never perform this moral act of inner revolution and that he will remain anchored in manipulation and cunning, or that he will never move past the horizon of prudence. In Anthropology, where Kant reflects on man's acquisition of character, he thematizes it in the same manner as he does in the context of moral conversion toward good; then he hazards a guess, and points out: "Perhaps only a few have attempted this revolution before the age of 30 , and even fewer have established it solidly before 40" (AA VII, 294). If we take into account that the life expectancy was then about 30 years, Kant's prognosis is not very encouraging.

Moreover, those few individuals, who have achieved this inner revolution and established good in themselves, will never be sure of having achieved it. Pure moral intention is an intelligible act that has a negative criterion of the absence of all empirical interest regarding the ultimate determinant of action, but we can never be sure of knowing everything empirical in reference to our desires. "Likewise the nonexistence of something (and so also, any advantage concealed in thought) cannot be an object of experience" ${ }^{\prime 4}$. Thus, "it is not possible for man to look so far into the depths of his own heart that he can ever be completely sure about the purity of his moral purpose and the cleanliness of his intention or so much as one of his actions, even if its legality is not subject to any doubt" $^{\prime 1}$. What the law mandates is that one strive to achieve that purity (AA VIII, 285; AA VI, 393) and if one ought, one can: "A change of direction [Sinnesänderung] must also be possible, because it is a duty" (AA VI, 66-67). Further, "duty commands us to be good, and duty does not command us to do anything that is not feasible" (AA VI, 47; see also 50). Nonetheless, we do not know our intelligible character directly, but rather only through our phenomenal or sensible character, that is, "only from its consequences in behavior," 42 and "so, true morality of actions (worth and guilt), and even of our own conduct, remains totally concealed from us" ${ }^{\prime 3}$. Still, a man comparing his past and present actions can have some confidence about his change of intention during his life (AA VI, 68). We can add that not being totally sure of one's good will, protects one from the potential arrogance and vanity that would destroy it.

40 "Auch überhaupt kann das Nichtsein von Etwas (mithin auch nicht von einem insgeheim gedachten Vorteil) kein Gegenstand der Erfahrung sein“" (AA VIII, 284).

41 As we read in Kant's Metaphysik der Sitten: “Denn es ist dem Menschen nicht möglich so in die Tiefe seines eigenen Herzens eizuschauen, daß er jemals von der Reinigkeit seiner moralischen Absicht und der Lauterkeit seiner Gesinnung auch nur in einer Handlung völlig gewiß sein könnte; wenn er gleich über die Legalität derselben gar nicht zweifelhaft ist" (AA VI, 392).

42 “... nur aus den Folgen derselben im Lebenswandel“ (AA VI, 71; see also 77).

43 "Die eigentliche Moralität der Handlungen (Verdienst und Schuld) bleibt uns daher, selbst die unseres eigenen Verhaltens, gänzlich verborgen" (Kant, CPR A 551/B 579, note). "Perhaps never has a man done his duty in an absolutely disinterested manner (without the admixture of other motives)" [Vielleicht mag nie ein Mensch seine erkannte und von ihm auch verehrte Pflicht ganz uneigennützig (ohne Beimischung anderer Triebfeder) ausgeübt haben] (AA VIII, 284-285). 


\section{The Long Road of Virtue}

This final section leads us to the fourth moment of moral freedom, namely, the long process of virtue. This fourth moment presupposes and depends on the other three. In this genesis, the stages are based on one another. From the first moment, arises the possibility of always being able to go from an evil Gesinnung to a good one, but also the reverse, and consequently, the individual's responsibility for all of his actions. The second moment, of the decision for evil, leaves behind a tendency toward evil [Hang zum Bösen] in human nature that originates in this intelligible act of freedom and that gives rise to its own reality in the human world: its inertia, its interests, its injustice, and its practices and abuses, which are manifest, for example, through the violence of the strong and powerful, the corruption of criminal organizations, and the domination of dictatorial or fascist political regimes, and so forth (AA VI, 24-25, note; 25; 44; 47-48; 74; also AA VII, 294). The third moment of the inner moral revolution introduces freedom and its moral law as the ultimate guides of action. However, and here the fourth moment commences, in order to fulfill and realize this foundation of good in practice, the moral subject must overcome the propensity to evil already created, which has become customary and gained strength in himself and his society, by defeating its powerful presence of evil in the world. This requires "a continuous progress to infinity of an imperfect good toward a better one," ${ }^{44}$ or an asymptotic progress toward the unattainable goal of perfection [Vollkommenheit] (AA VI, $45 ; 60-61 ; 68 ; 122$ ) in this life and, for Kant, in a future life as well.

Moreover, not only the world and the empirical I must be transformed according to the new moral intention or Gesinnung, but this Gesinnung must itself be converted within freedom into a holy will, that is, into a will that is always good. The moral goal and ideal is a Gesinnung that does not allow itself to be affected by inclinations in its first principle of action but that always follows the moral law with complete confidence and certainty. Of course, as a finite being, man cannot help but feel interested in the needs stemming from his dependency on the world, and consequently, he will find himself continuously at a crossroad between two interests, forces, and constitutive elements: her originarity and finitude. Sometimes there will be discrepancies between them and he will have to choose which one to prioritize. For this reason, man's moral state can only be "virtue, that is, moral intention and struggle, and not holiness in the intended possession of a complete purity in the intention of the will"45.

In Religion, Kant proposes that the individual could receive assistance from an ethical community, which he designates as the intelligible church or the invisible church [die unsichtbahre Kirche] wherein all the visible churches would need to converge. However, we can add that if an individual lived in a just society, or a rational legal community, which recognized everyone's

44 As in Kant's Religion: “... ein continuirlicher Fortschritt von mangelhaftem Guten zum Besseren ins Unendliche" (AA VI, 67).

45 "Tugend, d.i. moralische Gesinnung im Kampfe, und nicht Heiligkeit im vermeintlichen Besitze einer völligen Reinigkeit der Gesinnungen des Willens" (AA V, 84). We do not have a holy will but rather are always affected by the pathological $(\mathrm{AA} \mathrm{V}, 32)$. 
freedom in its laws and institutions, it would help him tremendously and make it easier for him to decide in himself to do good than if he lives in an unjust or delinquent community, which would require of him greater will power and stronger character, or even heroic spirit.

Therefore, although Kant presented the installation of the good in the human spirit as an inversion of principles that contained no degree but only the yes and no, from the human point of view (AA VI, 48) moral intention or spirit has a long way to go toward reinforcing its good decision, which we can understand through the weight, interest, or inertia of the second moment and through human fragility and impurity. It is as if there were a certain mix or oscillation between good and evil principles in the human spirit, even after the presence of the good began to have its effect progressively. Although there is no degree in these principles themselves, there is a degree in their efficient force and its effects.

It is from this ongoing struggle that the postulate of immortality in the Dialectic of $\mathrm{KpV}$ departs. Practical reason wants perfection, but man, at best, is only capable of an asymptotic approximation of it. Very well, and this is the argument: Insofar as reason cannot demand the impossible, or otherwise it would be absurd, then if one ought, one can. Consequently, the just must be granted an eternity beyond death in order to fully satisfy the demand of reason, and not only to improve the world morally, because it disappeared with death, but to convert their Gesinnung into a permanent good will, or a holy will. I say "the just," because the unjust, Kant affirms, who, even frequently trying to propose the good, have always fallen back into evil and ever more deeply, will not do better in a life to come.

This postulate is without doubt Kant's coup de force, aided, obviously, by his culture and Christian religion, which was for him the only moral religion (AA VI, 48). However, it is worth noting that this postulate contains some contradictions, as occur whenever we attempt to think we can reach perfection, completion, or totality, which is when we enter the dialectic. We can, first, assume that in this postulate, freedom is thought as a transcendent substance that could be without a world, but then freedom ceases to be an original act of transformation of reality in nature and thus is thought in an isolated manner as a thing. Second, since the world has disappeared after death, and with it the dependency and finitude of man has also been eliminated and thereby, all tension between finitude and freedom, and between inclinations and moral law, then the very phenomenon of morality, and with it all subjective freedom and all consciousness have been annihilated as well ${ }^{46}$. Kant already warned us in the Prologue of Kant's KpV: "we can affirm that we do not know or understand, I am not saying simply the reality, but even the possibility" of the ideas of God and immortality ${ }^{47}$.

This said, we might conclude that the fourth moment is always open to us and that an unattainable ideal need not be absurd, but it is a constitutive tension of all subjectivity,

46 It could be suggested that, in order to remain human, finite, rational beings, after death we would go on to inhabit another world on which we would also depend. However, in this case, we would be making up a metaphysical fiction.

47 “... also können wir von jenen Ideen auch, ich will nicht bloß sagen, nicht die Wirklichkeit, sondern auch nicht einmal die Möglichkeit zu erkennen und einzusehen behaupten“ (AA V, 4). 
which provides us not only consciousness of our originarity, but also of our essential finitude, whereby we perceive ourselves as not self-sufficient, and this opens us up to the other: nature, other rational beings, and the divine. There is no omnipotence and this finitude is, I believe, the price we pay for our freedom and consciousness.

\section{References}

Kant I. 1900-. Gesammelte Schriften. Berlin: Akademie-Ausgabe (AA).

Kant I. 1996a. Practical Philosophy, trans. and ed. by M. J. Gregor. Cambridge: Cambridge University Press.

Kant I. 1996b. Religion and Rational Theology, trans. and ed. by A. W. Wood \& G. di Giovanni. Cambridge: Cambridge University Press.

Kant I. 1998. Critique of Pure Reason [abbr. CPR], trans. and ed. by P. Guyer \& A. Wood. Cambridge: Cambridge University Press.

Kant I. 2000. Critique of the Power of Judgement, trans. and ed. by P. Guyer. Cambridge: Cambridge University Press.

Philonenko A. 1981/3. L'œuvre de Kant. Paris: J. Vrin.

Plato 1925. Statesman, Philebus, Ion. Greek with trans. by N. H. Fowler \& W. R. M. Lamb. Loeb Classical Library 164. Cambridge, Mass.: Harvard University Press.

Rivera de Rosales J. 2007. “Los dos conceptos del mal moral. De La Religión (1793) de Kant a la Ética (1798) de Fichte", Signos Filosóficos 9(18):9-40.

Rivera de Rosales J. 1998/2002². Kant: la „Crítica del Juicio teleológico” y la corporalidad del sujeto. Madrid: UNED.

Rivera de Rosales J. 2007: “Kant: la buena voluntad," in idem, Cómo se comenta un texto filosófico (pp. 121-147). Madrid: Editorial Síntesis.

Schelling F. W. J. 1856/61. Sämmtliche Werke. Stuttgart - Augsburg: Cotta. 